\title{
Indonesian Navy as a Maritime Command Center Sea Defense Strategy
}

\author{
Suhirwan $^{1} \quad$ Lukman Yudho Prakoso ${ }^{1}$ Wuri Retno Martani ${ }^{2}$ \\ 1.Lecturer of Indonesia Defense University \\ 2.Magister Student of Indonesia Defense University
}

\begin{abstract}
The plan in relocating the new capital of Indonesia in Kalimantan must also be accompanied by preparing a new optimal defense system to anticipate all forms of threats, especially from the sea. The purpose of this study is to find the best marine defense strategy, in order to secure the New Capital City. This study uses the theory of public policy implementation of George Edward III, with the subfactors of communication transmission, communication clarity and communication consistency. Method used in this research is phenomenology descriptive qualitative. The results oh the analysis and discussion show that in the transmission subfactor, communication is only limited to each internal law enforcement entity,which there are no tactical operational transmissions at sea. In communication clarity subfactor, the communication between law enforcement entities is also not optimal since the existence of law enforcement entities in Makassar waters is incomplete with the infrastructure as well as other facilities, especially related to the communication equipment issue. Meanwhile, in subfactor of communication consistency, the existence of regulations on each entity as the operational basis at sea requires an effective and efficient bureaucratic procedure. Therefore, the conclusion of this research is that there is a great interest associated with securing a new capital city in East Kalimantan. Communication among the law enforcement entities in Makassar sea region, especially those who is dealing with ALKI II Makassar must be a priority. In order to optimize the performance effectively and efficiently, hardware, software, and brainware must be integrated. Hardware is the physical equipment of communication infrastructure, software is a regulation which strengthens the integration of communication systems and brainware is the conditiioning of personnel from every law enforcement entity at sea that there are very important national interests as priorities above the interests of sectoral egos.
\end{abstract}

Keywords: Sea Defense, Strategy, Communication

DOI: $10.7176 / \mathrm{PPAR} / 10-2-03$

Publication date: February $29^{\text {th }} 2020$

\section{Introduction}

The various forms of threats that must be faced are increasingly diverse. The dynamics of the strategic environment at the global, regional and domestic levels present a very broad spectrum of threats; ranging from threats to environmental and resource security, shipping security, human security at sea, to threats to state sovereignty (Suhirwan and Prakoso, L.Y., 2019). Moreover, in interconnected seas, forms of threat are always dynamic and difficult to predict. Therefore, the responsibility to guarantee stability and security in Indonesian waters which is one of the tasks of the Indonesian Navy carries complex challenges. The Indonesian Navy has a task that is currently increasingly prominent, in line with government policies to make the maritime sector a priority in national development, or better known as the vision of developing Indonesia to become the World Maritime Axis. The success of the Navy in realizing maritime security in Indonesia (Suhirwan and Prakoso, L.Y., 2019), is one of the preconditions for the successful achievement of this vision, in the table below is one of the challenges in securing the territorial waters of Indonesia, namely crime of ship robbery. The table below shows data on ship robberies around the world. 
Tabel 1. Data on Ship Robberies Around the World from 2009 to 2018

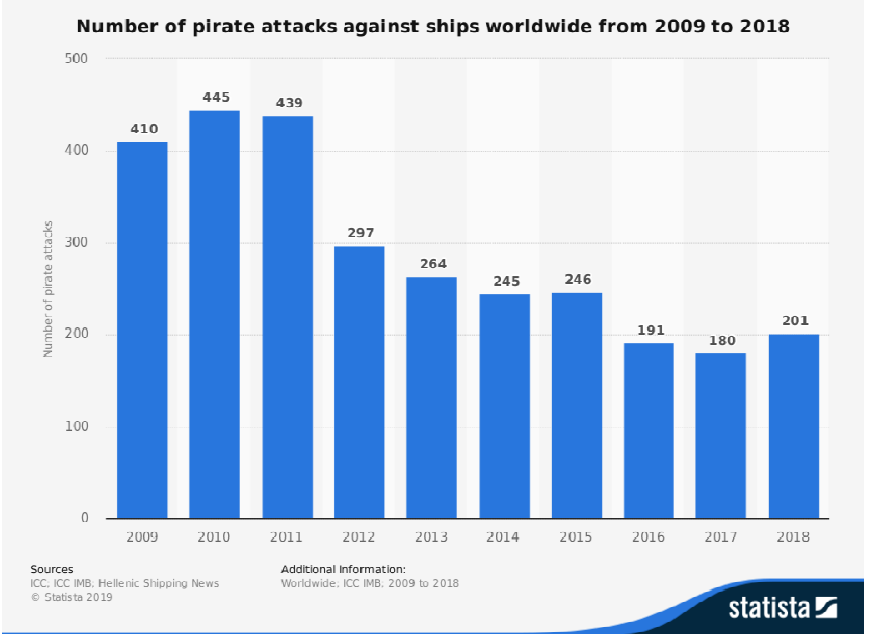

Source: ICC; ICC IMB; Hellenic Shipping News. 2019

Indonesia's efforts to gain international recognition as an archipelagic country have an impact on the responsibility for providing the Indonesian Archipelagic Sea Channel (ALKI). The flow is used by various countries for transportation both ships and aircraft. ALKI is not only prepared by Indonesia as a sovereign country over the archipelagic sea territories, but has a great responsibility to guarantee the safety of anyone who uses ALKI. This is not so easy to implement by Indonesia, given the various limitations that are also related to the territory of neighboring countries which are not yet fully felt safe. like ALKI III that goes through the Philippine sea area.

Philippine sea area is currently still a concern of the international community due to frequent piracy of ships, by holding several crew members from various countries. The signing was followed by a ransom request for a very large amount of money. This condition makes special attention in securing ALKI in Indonesia, especially ALKI III.

Figure 1. Map of the Indonesian Archipelago Sea Channel (ALKI)

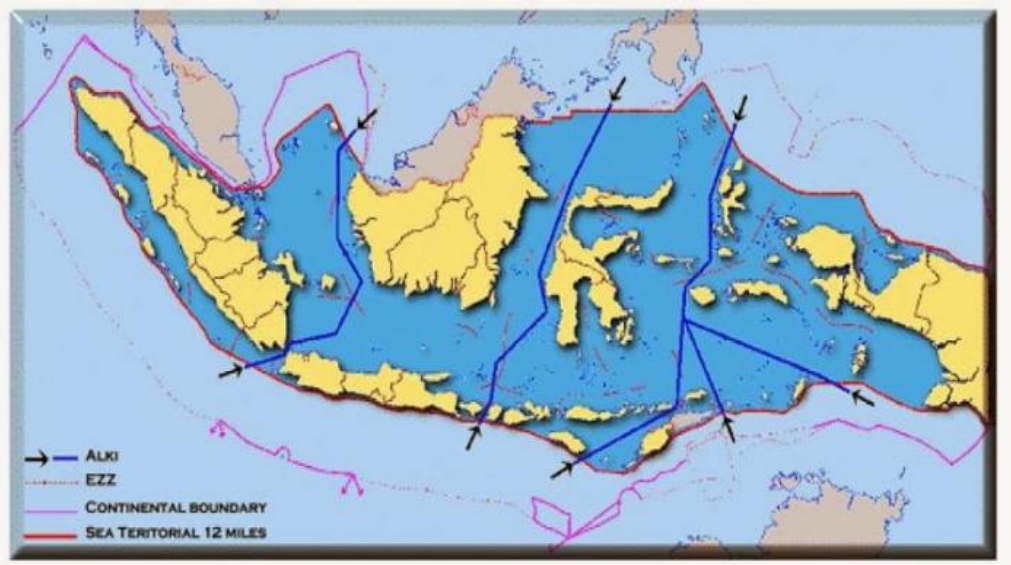

Source: based on Indonesian Government Regulation No.37 of 2002

According to Government Regulation No. 37 of 2002, about ALKI mentioned that there are 3 ALKI in Indonesia.

1. ALKI I includes shipping lanes from the South China Sea across the Natuna Sea, Karimata Strait, Java Sea, and Sunda Strait to the Indian Ocean, and vice versa; and for shipping lanes from the Singapore Strait through the Natuna Sea and vice versa (Sea Channel Branch I A).

2. ALKI II shipping lanes from the Sulawesi Sea crossing the Makassar Strait, Flores Sea and Lombok Strait shipping lanes to the Indian Ocean, and vice versa.

3. ALKI-III-A shipping lanes from the Pacific Ocean crossing the shipping lanes of the Maluku Sea, Seram Sea, Banda Sea, Ombai Strait, and Savu Sea. ALKI III-A shipping channel itself has 4 branches, namely ALKI III. B shipping line branch: for shipping from the Pacific Ocean across the Maluku Sea, Seram Sea, Banda Sea, and Leti Strait shipping lanes to the Indian Ocean and vice versa; ALKI shipping lane Branch III C: for shipping lanes from the Pacific Ocean across the Maluku Sea, Seram Sea, Banda Sea to the Arafura Sea and vice versa; ALKI shipping lane Branch III D: for shipping lanes from the Pacific Ocean across the Maluku Sea, shipping lanes of the 
Seram Sea, Banda Sea, Ombai Strait, and Sawu Sea to the Indian Ocean and vice versa; ALKI shipping lane Branch III E: for shipping lanes from the Indian Ocean across the Savu Sea, Ombai Strait, Banda Sea, Seram Sea and Maluku Sea.

Every ALKI shipping channel has a factual and potential threat. The threat must be addressed immediately by implementing a sea defense strategy. In the current research conducted in ALKI II, especially in the territorial waters which are under the authority of Makassar's Lantamal VI with the consideration that the government has decided to move the capital to East Kalimantan. So the current research aims to optimize sea defense strategies, especially on communication factors between law enforcement entities at sea who carry out operations in the ALKI II region, especially in waters that are under the authority of the Makassar Lantamal VI.

\section{Literature Review}

Research on the implementation of sea defense strategies in the Makassar Lantamal VI working area uses the theory of public policy implementation according to George C. Edward III. According to George Edward III, there are four factors that determine the success of a public policy implementation, namely communication, resources, disposition and bureaucratic structure (Edward III, 1980). In this study, which will be used to analyze the problem only on communication factors with sub-factors are communication transmission, communication clarity and communication consistency. The researcher only took one factor, namely communication because from previous studies that have been carried out by both other people and the researchers themselves, that this communication factor is the biggest inhibiting factor that has occurred in the effort to implement sea defense strategies in each of Indonesia's jurisdictional waters.

\section{Research Methods}

In the study of the implementation of the marine defense strategy in the Makassar Lantamal VI working area, researchers used a qualitative descriptive method with a phenomenological approach. The phenomenological approach used is according to Johann Heinrich Lambert. The intended phenomenological approach used in this research approach is as a basic theory of appearance to study empirically about the knowledge of sensory sightings (Cresswell, 1998).

The researcher collected secondary data from various sources and collected primary data from wellinformed resource persons related to the implementation of the sea defense strategy in Makassar waters, who were directly involved. The resource persons whose opinions are requested provide information and information according to their respective experiences based on the phenomena they experience.

Some of the entities involved in this study are the Directorate of North Sulawesi Police, the Sulbangsel Customs, KPLP Makassar Soekarno Hatta Port and Untia Makassar Fisheries Port Head.

\section{Results And Discussion}

Implementation of Communication Factors between Law Enforcement Entities at Sea.

The communication factor is a very important factor in the implementation of the sea defense strategy in securing the Makassar waters, especially in securing national and international interests in using the ALKI II shipping lane. The implementation of this communication factor guarantees effective implementation of ALKI II security, if decision makers know what they are going to do (Agustino, 2006).

In implementing ALKI II, information is needed that is known by decision makers which can only be obtained through good communication, internal entities involved and between entities that have the same task in securing the Makassar waters. A very important communication subfactor is divided into a communication transmission subfactor, a communication clarity subfactor and communication consistency:

Communication Transmission. In the implementation of the marine defense strategy in the Makassar waters, a good channel of communication between law enforcement entities will be able to produce a good implementation as well. There are often problems between law enforcement entities in communication distribution, namely misunderstanding (miscommunication) due to the many levels of bureaucracy between law enforcement entities that must be passed in the communication process, so that what is expected in the implementation of the marine defense strategy in the Makassar region is distorted in the middle of the road.

Makassar Lantamal VI Operations Assistant said that the transmission of ALKI II communication between Lantamal VI and related agencies, in this case the stakeholders at sea were well maintained. This was implemented with a joint coordination forum in each agency in turn to strengthen relations between agencies. However, different information was obtained by researchers from informants in the KPLP that in the operational security that is the area of responsibility, it was constrained by communication tools. If the security area is covered by their cellular network, they can easily contact or coordinate with other law enforcement entities, but if it is not covered by the cellular network, the radio communication equipment on their patrol boat cannot contact other entities.

Clarity of Communication. The implementation of the marine defense strategy in the Makassar waters area 
related to the clarity of communication received by the policy implementing entity (street-level-bureaucrats), must be clear and not confusing between law enforcement entities at sea or unambiguous / ambiguous. Related to this, the Makassar Lantamal VI Asop said that, the clarity of monitoring information between Lantamal VI and stakeholders at sea was placed in accordance with the rules of authority contained in the existing and applicable laws. For example, the authority to enforce law at sea has been regulated in a law stating that there are 7 (seven) law enforcement entities that have the authority to enforce law at sea, including the Navy, Ditpolair Polri, Ditjen Hubla Kemenhub, Ditjen PSDKP Ministry of KKP, Ditjen Beacukai Ministry of Ministry Finance, Bakamla and Task Force 115 Task Force to Eradicate Illegal Fishing.

Communication Consistency. The implementation of the marine defense strategy implemented in Makassar waters requires that commands given in the implementation of a communication in securing the Makassar waters have to be consistent and clear to be established or implemented. If the order to safeguard Makassar's territorial waters given frequently changes, it can cause confusion for implementing entities in the field. Related to the Makassar Lantamal VI Asop related to the Consistency of Communication between Law Enforcement at Sea in the Makassar Lantamal VI Work Area: The consistency of ALKI II supervision between Lantamal VI and related agencies in the waters of Sulawesi has been going well according to the existing legal basis so we always stick to adhere to the laws and regulations as paying law to act in the field.

Based on the research results of the sea defense strategy in the Makassar region, there are several obstacles in the communication factor as stated by Edward III related to the implementation of a policy in the communication transmission subfactor, namely (Winarno, 1984):

The first obstacle is that there is a conflict between the implementing entity of the policy and the order issued by the policy maker. From the Customs informant, it was conveyed that there were individuals from certain entities who did not fully understand the existing regulations so that conflicts in the field often occurred. Conflicts between entities implementing a marine defense strategy like this will result in distortion and direct obstacles in policy communication.

The second barrier is information that is conveyed internally by law enforcement entities, and between law enforcement entities through layers of a bureaucratic hierarchy. Distortion of communication between law enforcement entities can occur due to the length of the information chain which can result in information bias.

The third obstacle is the problem of capturing information between entities also caused by perceptions and the inability of law enforcement entities in the implementing sea to understand the requirements of a law enforcement policy.

In implementing the sea defense strategy in the Makassar waters, there are factors that encourage this uncertainty due to the complexity of the policy, lack of consensus of law enforcement entities regarding the objectives of securing the Makassar waters, there are problems in starting a new policy related to law enforcement at sea, and there is a tendency to avoid policy accountability.

From the results of research in Makassar, actually at the leadership level among law enforcement entities involved in the implementation of the marine defense strategy in Makassar is well established, with the existence of a regional leadership communication forum. However, it cannot be denied that there are persons who have certain goals which are spared from the leadership's supervision. This can be an obstacle considering the vast area of Makassar's waters with various constraints and limitations of law enforcement. The cause of this communication distortion is in line with what was conveyed by Winarno (2005: 129) that the more layers or implementing actors involved in policy implementation, the more most likely obstacles and distortions faced. This is also the case with the implementation of the marine defense strategy in the Makassar Sea.

In the implementation of the marine defense strategy it is necessary to manage good communication between law enforcement entities, it is necessary to establish and develop effective communication channels internally and externally. The better the development of communication channels between the entities that are built, the higher the probability of the commands in the successful implementation of the sea defense strategy in the Makassar area is continued correctly.

In the implementation of the marine defense strategy in the Makassar waters area, information clarity is needed, it is found that there is a tendency to obscure the objectives of information by individual actors of certain entities based on their own interests by interpreting information based on their own understanding. So that the implementation of the marine defense strategy can be optimal, the way to anticipate obscuring such actions is by making joint procedures between law enforcement entities through clear statements about strengthening commitment requirements, commitment to objectives, eliminating the choice of multi-interpretation between law enforcement entities, commitment to implement procedures with care careful and committed reporting mechanisms in detail.

In the implementation of the marine defense strategy, the communication factor is very influential on the acceptance of the policy by the target group of law enforcement entities, so that the quality of communication will influence in achieving the effectiveness of the implementation of the sea defense strategy. Thus, the dissemination of policy content through a good communication process will affect the implementation of the 
marine defense strategy. In this case, the communication media used by law enforcement entities, to disseminate the contents of the sea defense strategy policy to the target group, will play a major role in securing the Makassar Sea.

\section{Communication Factor Optimization between Law Enforcement at Sea}

Based on the analysis and discussion of the implementation of ALKI II safeguard communication factors conducted by Lantamal VI Makasaar, associated with supporting and inhibiting factors as well as the current and expected implementation conditions, the researcher can formulate the following strategies:

"Building a Maritime Command Center by placing a Navy Base in each Indonesian Sea Area as a Command Center"

Based on the results of the analysis and discussion of the implementation of the marine defense strategy currently in the Makassar Lantamal VI working area, it can be explained as follows:

The current condition of the prominent threat is related to drug smuggling, especially those that have been very rife, this smuggling comes in from various sea and land areas. If this is not immediately taken concrete steps, it is very likely that other crimes will also develop so that strategic steps need to be taken to immediately resolve the problem of surveillance and control of the sea area, especially ALKI II in Makassar Lantamal Region VI.

Factual and potential threats that occur in Makassar Sea that still dominate are transnational crime (TNOC), illegal drug trafficking of seepage from the Sebati-Tawau border region of Malaysia, some of which is smuggled on the coasts of the Western Region of South Sulawesi. In addition, smuggling of used clothing is also still common. The findings in this study are new patterns found related to drug smuggling and used clothing, namely the route from Timor Leste. The smuggling route from Tawau into Timor Leste, then from Timor Leste transported by wooden ships to several regions of Indonesia including into the Sea of Makassar.

Another problem related to threats occurring at sea is the rise of fish bombing cases, according to the informant of the port head of Untia Makassar, which is unique that many of these actors are underage so that they are not continued in the legal process, they are fostered in the Makassar social shelter near the Untia Makassar Fishing Port, at one time the number was quite large to more than 50 people. Law enforcement entities at sea continue to take action against fish bombers. The number is currently decreasing considerably, but there are still several cases.

At present there are 6 law enforcers who have the capacity to conduct law enforcement patrols at sea operating in the Makassar Lantamal VI region. Each has its own operating pattern. Based on the analysis and discussion it was revealed that actually each entity has the same limitations, especially human resources and facilities to carry out patrols. For example PSDKP Ministry of Makassar KKP, according to its authority has the task of overseeing the waters in terms of fishing outside the district and provincial boundaries above 12 nautical miles. But only has a small speedboat, which is only capable of patrolling along the coast, as well as Polair, Customs and KPLP.

Adequate Patrol Vessels in the Makassar area are owned by Makassar Lantamal VI and even now are also facing problems due to government policy to use B20. This policy is quite an obstacle because the Navy ships have not yet received equipment that is able to convert B20 to become fuel that can be used for operations at sea. Navy ship engines when using B20 there must be additional equipment so that B20 can be used to operate the ship's engine.

The Makassar water area is very important with the existence of the ALKI II shipping lane that crosses the Makassar Strait. This shipping channel has a strategic role for Indonesia. The opportunity for Makassar to utilize ALKI II is very potential for economic interests. So far, Makassar has been seen as a gateway to the economy of eastern Indonesia, where trade flows through Makassar before entering eastern Indonesia.

Makassar's current strategic position has also become prominent because of the Government's decision to move the Capital City to the Kalimantan Region in Penajam Regency, East Kalimantan. The closest Indonesian Navy force is Makassar's Lantamal VI, so the current research is very much related to how to optimize the sea defense strategy in the Makassar waters which is the working area of Makassar's Lantamal VI. The new Capital Territory is directly confronted with ALKI II, where the channel is traversed by international interests. Vulnerability will arise with potential threats that must be anticipated as early as possible.

The current policy of the Indonesian Minister of Defense that national defense is the responsibility of all layers (universal defense), means that the problem of defense is not only the responsibility of the TNI / Military but all state entities, and all levels of society must take responsibility for maintaining Indonesian sovereignty. Budget constraints are indeed a major obstacle, but because of this reasoning is needed, a concept of how each defense strategy implemented can be carried out effectively and efficiently. With all the limitations that exist must be able to find the best strategy, especially in securing sea areas.

In this study, the communication factor becomes very important, with the hope that if the communication factor between law enforcers at sea can find the best solution, it is hoped that there will be further solutions for 
other factors. Operational synergy is an expected goal in the current research by promoting communication factors, both in terms of communication transmission, communication clarity and communication transmission between law enforcement entities at sea that support the implementation of a reliable sea defense strategy.

Regarding the current national public policy, the Omnibus Law is being initiated, currently preceded by policies related to the economy, namely the field of taxation. One of the objectives of this policy is to simplify the many overlapping regulations so that they become obstacles in economic development. The spirit of this regulation can be applied in various fields such as law enforcement at sea. The existence of authorized entities in law enforcement at sea, creates obstacles in terms of communication, because each entity has its own policy base.

Research related to the implementation of the marine defense strategy carried out in Makassar waters, can be a model to be applied in various territorial waters of Indonesia, so that Indonesia's sea defense becomes stronger. The synergy of law enforcement at sea will also have an impact on the economy, for example a small example that sea transportation businesses are often troubled by repeated checks by different law enforcement entities, complaints from entrepreneurs must be considered because they are very detrimental to business actors. They lost a lot of time, whereas they already have a commitment with the user regarding the delivery time.

The policies which form the basis of the operation of law enforcement entities at sea, which are the main force of the sea defense strategy, often become obstacles due to overlapping authority in the field. Both among the law enforcement entities and those affected by the policy as explained above, often sea transportation operators are repeatedly examined with different entities. The overlapping policy makes ambiguous by some parties as well as those affected by the policy, the ambiguity of this policy arises as stated by Matland (1995).

It cannot be denied that the Indonesian Navy, among law enforcement entities at sea, is the entity that has the most complete and most ready bureaucratic structure if it becomes a Command Center for sea surveillance and control. So that in the strategy of building a Maritime Command Center there are 2 things that become significant:

1. Change the network that originally used the Star Network to become a Wheel Network. From the star network image it can be seen that the current network takes a long time and process, because each law enforcement entity coordinates with each other law enforcement entity. Meanwhile, if we consider the Wheel Network. Will be very effective with the Command Center, because all the needs will be a movement controlled by one party. With the hope that there is no overlap in patrol areas and effectiveness and efficiency can be obtained. From this strategy patrol zoning can also be built for supervision and control.

2. Currently, each entity that has a duty to patrol at sea in the context of law enforcement at sea has its own policy base, so the next step in implementing the Maritime Command Center strategy is synchronizing policies. If this step is considered to take a long time and high difficulty, then steps can be taken by issuing a new policy to support the implementation of the Maritime Command Center strategy by stating that if the existing regulation contradicts the new policy, the Navy in the relevant area acts as Command Center decides.

The Novelty of this research that place the Navy as the Command Center for maritime control in optimizing sea defense strategies in Makassar waters are in line with Kent Booth's (1977) theory which says in his book entitled "Navies and Foreign Policy" that the Navy has a universal role which is not owned by other law enforcement officers at sea such as Polair, Customs, Bakamla and other entities in carrying out their duties, the roles are:

1. The role of the Navy (Millitary). That the Navy has a role in upholding the sovereignty of a country using its military force, from all forms of threats in the sea area that becomes its jurisdiction.

2. The role of the Navy Constellation. That the Navy has the authority to enforce law at sea, conduct activities in the context of protecting national marine resources and assets, take measures to maintain order at sea, and carry out activities in the context of supporting national development by carrying out activities that contribute to national stability and development

3. The Role of Naval Diplomacy. That the Navy can use sea power as a means of diplomacy, to support the foreign policy of a country's government, and is designed to be able to influence state leadership or decisions of several countries in a peaceful state or in hostile situations.

These three roles cannot be separated from the duties of the Navy universally so that in the selection and determination of the National Defense Strategy at Sea must also be able to reflect a strategy to deal with security disturbances.

\section{Conclusion}

The implementation of ALKI II security by the Makassar Navy Base IV has so far been going well. The existence of a communication forum between entities is still the mainstay to carry out the supervision and control of sea areas, especially related to ALKI II. Handling threats at sea is still dominated by criminal acts both 
traditional in nature such as the use of fish bombs and those that are transnational crimes related to drug smuggling and Ball Press. Overcoming inhibiting factors The implementation of ALKI II safeguards by the Indonesian Navy Base IV Makassar is an urgent need that must be immediately met by the central government in cooperation with the relevant Regional Governments, in the context of preparing the transfer of the New Capital City.

Based on the results of the analysis and discussion, the formulation of a strategy to guarantee the security of ALKI II and can be applied to each ALKI pathway for optimization of communication factors in this study is: "Building a Maritime Command Center by placing the Navy Base in each Indonesian Sea Area as a Command Center". Strengthening the Maritime Command Center strategy requires government policy support as an operational basis by synchronizing all existing regulations or making new regulations with a single strengthening placing the Navy Base as a Command Center in each sea area that is its responsibility.

As a recommendation of the current research with the momentum of the government to implement the omnibus law, now is the right time to implement the findings of this study, making a law enforcement policy at sea in order to strengthen the marine defense strategy by placing the Navy as the Maritime Command Center.

\section{REFERENCES}

Agustino, Leo. (2006). Dasar-Dasar Kebijakan Publik. Bandung: CV. Alfabeta

Creswell, John W. (1998), Qualitative Inquiry and Research Design, Choosing Among Five Traditions. California: Sage Publication. Hal 65

Edward III, Georde C. (1980). Implementing Public Policy. Washington DC: Congressional Quarterly Press.

ICC; ICC IMB; Hellenic Shipping News. 2019

Ken Booth, Navies and Foreign Policy, London, Croom Helm, Ltd, 1977.

Matland, Richard E. (1995) Syntesing the Implementation Literature: The Ambiguity-Conflict Model of Policy Implementation. Journal of Pubic Administration Research and Theory. Vol.5, No. 2

Peraturan Pemerintah No.37 tahun 2002 Hak Dan Kewajiban Kapal Dan Pesawat Udara Asing Dalam Melaksanakan Hak Lintas Alur Laut Kepulauan Melalui Alur Laut Kepulauan Yang Ditetapkan

Suhirwan, Lukman Yudho Prakoso. (2019). Defense strategy at sea handling of Transnational Organized Crime (TNOC) in Nunukan Indonesia's national sea border. IOP Conference Series Earth and Environmental Science 339:012043, DOI: 10.1088/1755-1315/339/1/012043

Suhirwan and Lukman Yudho Prakoso. (2019). Forum Maritim Kunci Sukses Penanggulangan Ancaman Asimetris di Selat Sunda, Conference: Seminar dan Lokakarya Kualitatif Indonesia: Pengembangan Budaya Penelitian Menuju Indonesia 4.0, DOI: 10.33510/slki.2019.13-20

Winarno, F. G. (1984). Kimia Pangan dan Gizi. Jakarta: PT Gramedia Pustaka Utama. 